\title{
Do gold prices respond to real interest rates? Evidence from the Bayesian Markov Switching VECM model
}

\author{
Nicholas Apergis ${ }^{\mathrm{a}, \mathrm{b}, *}$, Arusha Cooray ${ }^{\mathrm{c}}$, Naceur Khraief ${ }^{\mathrm{d}}$, Iraklis Apergis ${ }^{\mathrm{e}}$ \\ ${ }^{a}$ School of Finance and Statistics, University of Piraeus, Greece \\ ${ }^{\mathrm{b}}$ University of Derby, UK \\ ${ }^{\mathrm{c} S}$ School of Economics, University of New South Wales, Australia \\ ${ }^{\mathrm{d}}$ Tunis Business School, Université de Tunis, Tunisia \\ ${ }^{\mathrm{e}}$ Business School, University of Kent, UK
}

\section{A R T I C L E I N F O}

\section{Article history:}

Received 16 January 2018

Accepted 26 December 2018

Available online $\mathrm{xxxx}$

\section{JEL classification:}

E40

$\mathrm{E} 43$

Keywords:

Gold

Interest rates

MS-VECM model

\begin{abstract}
A B S T R A C T
The goal of this paper is to examine the transmission dynamics between the real interest rate and gold prices in the G7. The methodology follows the Bayesian Markov-Switching Vector Error-Correction (MS-VECM) model, along with regime-dependent impulse response functions, spanning the period 1975-2016. The findings suggest a positive association between gold prices and real interest rates, with the estimates remaining consistently positive and statistically significant across all G7 countries. The results indicate that gold prices can provide hedging services against real interest rate movements mainly during recessionary times. Our results continue to be robust when we extend the bivariate version of our modeling approach to include more drivers for gold prices.
\end{abstract}

(c) 2018 Elsevier B.V. All rights reserved.

\section{Introduction}

One of the main factors which influence investment holdings is the real interest rate. As the real rate of interest falls, alternative assets become more attractive, and vice versa. During periods of low investor confidence, gold can be seen as an attractive substitute investment alternative. This association between gold and the real interest rate was first observed by Wicksell in as far back as 1907. During periods of crisis, gold has served as a hedge and stabilizing vehicle, leading to lower volatility movements in portfolios (Baur and McDermott, 2010; Belke, 2013). This is due to the unique features that gold carries compared to other assets, i.e. it does not perish, and it lacks default risks. Gold has acted as a security during times of crisis outperforming bonds and equities. History has demonstrated this. When Britain voted to leave the European Union in 2016 for example, gold prices rose by $\$ 100$ within six hours as investors began to buy gold in the face of a falling pound and euro. Similarly, in February 2009 gold reached $\$ 1000$ an ounce following the financial crisis. The U.S debt ceiling in the aftermath of the 2008 financial crisis, and the Eurozone debt crisis resulted in the price of gold rising from $\$ 1000$ an ounce in 2009 to $\$ 1895$ by September 2011 (Amadeo, 2017). The removal of the U.S dollar from the gold standard in 1976 was another event which led the price of gold to rise from $\$ 42$ to $\$ 120$ an ounce (Amadeo, 2017). Thus, high gold prices could be a signal of high inflation or a weak economy as investors see gold as a hedge during periods of crisis or recession. Low

\footnotetext{
* Corresponding author.

E-mail addresses: napergis@unipi.gr, n.apergis@derby.ac.uk (N. Apergis), ia239@kent.ac.uk (I. Apergis).
} 
gold prices on the other hand could be indicative of a healthy economy as investors have a number of alternative assets such as stocks and bonds from which to choose.

Gold prices can therefore, provide a useful informational content for the direction of economic activity and accordingly implementation of monetary policy. Given the unique properties of gold that motivate investors to increase their holdings during crises periods, it is important to understand the relationship between the real interest rate and gold prices. Thus, the objective of the present study is to investigate specifically the relationship between the real interest rate and gold prices. There are several channels through which gold prices and the interest rate might be correlated (O'Connor et al., 2015). Fortune (1987) presents an asset substitution channel through which increases in expected interest rates will cause investors to sell gold, pushing gold prices down. Similarly, Wang and Chueh (2013) find a negative relationship between shortterm interest rates and futures gold prices. If the rate of interest falls in the current period, investors expect exchange rate depreciation, moving their wealth into the gold market, thus, pushing up gold prices in the subsequent period. Over the long run, Wang and Chueh (2013) find that if the Federal Reserve lowers interest rates (with those changes in interest rates reflecting economic fundamentals), market participants see this as a sign of a future recession and, thus, shift their wealth into the gold market, pushing up again gold prices. Baur (2011) differentiates between short- and long-term interest rates in investigating their effect on gold prices. According to him, if the short-term opportunity cost of holding gold falls, while longterm inflationary expectations increase, gold prices will also increase. These findings suggest that gold prices rise if investors buy short-term bonds or sell long-term bonds. Cai et al. (2001) observe that macroeconomic announcements affect gold prices. It should be noted, however, that real interest rates cannot be observed in real time. If, therefore, increases in inflation are fully expected, then the inflation premium is fully incorporated into nominal interest rates and this would lead to increases in gold prices by the full amount of the increase in inflation. If, however, the expected capital gain from holding gold is high, the sensitivity of the demand for gold is also high relative to the expected increase in prices, which could cause gold prices to increase by more than the increase in the rate of inflation.

Many studies investigate the relationship between the real rate of interest and gold as one of many variables among other precious metals (Batten et al., 2013; Wang and Chueh, 2013; Bhar and Hammoudeh, 2011; Tulley and Lucey, 2007; Lawrence, 2003; Cai et al., 2001; Levin et al. 1994). Similarly, a number of studies examine the relationship between gold and inflation (Erb and Harvey, 2013; Batten et al., 2013; Bampinas and Panagiotidis, 2015). While our study is closely related to this literature, we contribute to the literature in the following ways: (1) we focus specifically on the relation between gold prices and interest rates using the sample of G7 economies as a basis for the analysis. These G7 economies are explicitly chosen because the financial behavior of these leading economies are of critical importance to other nations. Aizenman et al (2016) observe that for many financial variables the strength of the association with the major economies have been important in the last two decades. This has been particularly evident during crises periods. The conclusions of this study will therefore show if monetary policy of the G7 countries have implications for the global economy; (2) in order to achieve this objective, we use a Bayesian Markov-Switching Vector Error-Correction (MS-VECM) model. This yields the transition probabilities that the real interest rate and gold prices are moving jointly in a given regime. That is, causality from the real interest rate to gold prices would indicate that the two markets are integrated and that real interest rate changes can lead to changes in gold prices. This methodology also permits reconstructing regimes by inferring the probabilities of the unobserved regime, conditional on an available information set. Thus, this approach has the advantage of capturing changes in causality relationships due to regime changes.

The findings of this study indicate a positive relation between gold prices and real interest rates, with the estimates remaining consistently positive and statistically significant across all G7 countries. The results indicate that gold prices can provide hedging services against real interest rate movements mainly during recessionary times. Our results are robust to extending the bivariate version of our model to incorporate more factors influencing gold prices. The rest of this study is structured as follows. Section 2 discusses the literature. Section 3 presents the methodology and data. Section 4 evaluates the empirical results and Section 5 concludes.

\section{Literature}

This paper is closely related to the strand of literature that identifies the drivers affecting gold prices. In particular, a number of factors can influence the demand for gold and hence its price (O'Connor et al., 2015 for a detailed review of the literature). The interest rate, the exchange rate, the inflation rate, the returns on other commodities, such as oil and precious metals have been identified as such potential drivers. There is a large literature investigating the relationship between gold and inflation (Erb and Harvey, 2013; Batten et al., 2013; Bampinas and Panagiotidis, 2015), gold and oil prices (Ewing and Malik, 2013; Reboredo, 2013; Wang and Chueh, 2013), gold and exchange rates (Sjaastad and Scacciavillani, 1996; Capie et al., 2005; Tulley and Lucey, 2007), gold and other precious metals (Garbade and Silber, 1983; Ma, 1985; Wahab et al., 1994; Bhar and Hammoudeh, 2011).

Theoretical studies on gold prices and the rate of interest include those by Diba and Grossman (1984) and Fortune (1987). Fortune (1987) constructs a model relating gold price inflation to consumer and wholesale prices and the expected rate of interest. According to this model, given an expected level of future prices, an increase in expected interest rates will lead to a fall in the price of gold. The higher the expected interest rate in the future, investors will reduce purchases of, and increase the sale of gold to buy liquid assets, which will yield a higher expected rate of return. This transformation from gold to liquid 
assets is undertaken under the expectation that the price of gold will fall in response to the increase in expected future interest rates. Diba and Grossman (1984) put forward a theoretical model to investigate the possibility of a rational bubble in the price of gold. They argue that the time series of its price, as well as the differenced series should be non-stationary if a rational bubble should exist. The results indicate that the differenced series of gold prices is stationary. The empirical results also suggest a close correlation between the time series properties of the relative price of gold and the time series properties of the real interest rate, indicating that the price of gold responds to market fundamentals, which is not suggestive of a rational bubble.

On the empirical front, Cai et al. (2001), Lawrence (2003), Levin et al. (1994), Bhar and Hammoudeh (2011), Batten et al. (2013), Baur (2011), Tulley and Lucey, 2007, and Wang and Chueh (2013) among others, explore the relationship between gold prices and interest rates. Using an ARCH model, Cai et al. (2001) observe that macroeconomic announcements with regard to employment, gross domestic product, the consumer price index, and personal income, affect gold prices. They also note that the gold market price volatility exhibits long memory properties. By contrast, Lawrence (2003) reaches the differing results. Employing a Vector Autoregressive methodology and U.S data over the period 1975-2001, Lawrence (2003) investigates the relationship between gold and financial variables. His results report the absence of a statistically significant relationship between gold returns and changes in macroeconomic variables, including GDP, inflation and real interest rates. Similar results are documented by Tulley and Lucey (2007) who investigate the relationship between the price of gold and a number of variables, including the nominal rate of interest, stock prices, oil prices, exchange rates, inflation rates, and industrial production. Employing an Asymmetric Power GARCH (APGARCH) model, they do not observe any statistically significant relationship between nominal interest rates and gold prices. The U.S dollar is found to be the primary variable which influences gold prices. Employing a Markov model accounting for regime changes to investigate the relationship between four commodity prices: gold, copper, oil and silver and three financial variables: the nominal interest rate, the exchange rate and the world stock market, Bhar and Hammoudeh (2011) find that the association between commodity prices and financial variables are regime dependent. Out of the four commodities, oil prices are shown to have the strongest relationship with the financial variables in both regimes, while gold prices are found to have the least linkage with them. Batten et al. (2013) observe a significant time variation in the relation between gold and inflation in the past decade. They attribute to changes in the rate of interest. Examining the relationship between oil, gold prices, the interest rate and the U.S. dollar using threshold cointegration, Wang and Chueh (2013) find that nominal interest rates have a negative impact on gold prices and a positive effect on oil prices. Gold and oil prices are also found to influence the nominal interest rate. Baur (2011) argues that the relationship between gold and short- and long-term interest rates differs. In a study of whether gold is a store of value and a hedge against movements in macroeconomic variables, Baur (2011) observes that gold is a hedge against a lower US dollar and higher commodity prices over a 30-year period, spanning 1979 to 2010 . The results also indicate that lower short-term and higher long-term real interest rates influence the price of gold in a positive manner. His results suggest that gold prices increase if the short-term opportunity cost of holding gold decreases and long-term inflation expectations increase. Levin et al. $(1994,2006)$ similarly, find that gold acts as a long term hedge against inflation.

These previous studies provide a motivation for the present one. We however, focus specifically on the relation between interest rates and gold prices as opposed to many studies which examine the relation between interest rates and gold prices among prices of a number of other precious metals. Our dataset additionally covers the 2008 financial crisis period. We use a Bayseian MS (2)-VECM model to capture this relationship.

\section{Methodology and data}

\subsection{Methodology}

Regime-switching models were first introduced by Hamilton (1989) to U.S. GDP data. These non-linear models are broadly applied to financial and economic data (Hamilton, 1998; Lam, 1990; Garcia and Perron, 1996; Kim and Nelson, 1998 among many others). These models, which involve multiple structures, can characterize the time series behaviors across different regimes. These states have two common features: the past regimes are recurrent and the number of regimes is finite. By permitting switching between across regimes, this modeling method is capable of capturing more complex dynamic patterns.

Following these studies, this paper examines the time-varying dynamic relationship between real interest rates and gold prices by using the Markov Switching Vector Error Correction Model (MS-VECM) proposed by Krolzig (1999), which is a multivariate generalization of the Hamilton (1989) model. A MS-VECM model has been also applied by Sarno and Valenete (2005) for forecasting stock returns who illustrate regime-switching in the term structure of interest rates. This methodological approach predicts the presence of different regimes, where the parameters of a MS-VECM are designed to take a constant value in each regime and to shift discretely from one regime to the other. Such changes are considered as random events controlled by a Hidden Markov process with a finite number of states (regimes), which is defined by the transition probabilities. The MS-VECM is well suited for testing the hypothesis of independence, because it yields the transition probabilities that the real interest rate and gold prices are moving jointly in a given regime. In other words, causality from the real interest rate to gold prices points out that the two markets are integrated and that real interest rate changes can lead to changes in gold prices. In this model, it is also possible to reconstruct the regimes by inferring the probabilities of the unobserved 
regime, conditional on an available information set. Hence, this approach has the advantage to adequately capture changes in the causality relationships arising from switches in regimes. Accordingly, this approach allows us to identify the periods during which an appropriate causality holds (regime-dependent Granger causality) ${ }^{1}$.

Unlike the standard linear VECM model, which assumes a constant variance covariance matrix, the MS-VECM approach has an important characteristic that the contemporaneous covariance matrix of the residuals is also regime switching, and substantial differences across regimes emerge. Consequently, the conventional impulse response analysis is expected to lead to severely misleading results. Thus, in order to generate regime-dependent impulse responses with error bands, it is possible to use the Bayesian Markov-Chain Monte Carlo (MCMC) integration method of the Gibbs sampling (Ehrmann et al., 2003).

Concretely, we denote the real interest rate and gold prices by $R_{t}$ and $G_{t}$, respectively. Let $Y_{t}=\left[R_{t}, G_{t}\right]^{\prime}$ designate an $I(1)$ vector of bivariate time series with $r$ linear cointegrating relations. $A \operatorname{VAR}(\mathrm{p})$ system can be written as a Vector Error Correction Model (VECM):

$$
\Delta Y_{t}=\mu+\alpha \beta^{\prime} Y_{t-1}+\sum_{i=1}^{p-1} \Psi_{i} Y_{t-i}+\varepsilon_{t}
$$

where $p$ is the order of VAR model, $\varepsilon_{t} \operatorname{NID}(\mathbf{0}, \Omega)$ is a normally distributed Gaussian innovations and $\Omega$ is a $(2 \times 2)$ positive definite covariance matrix, $\alpha(2 \times r)$ is the adjustment term, $\Psi_{i}$ is the lag term and $\beta^{\prime}(2 \times r)$ is the cointegrating vector. It is assumed that the MS-VECM parameters $\theta \equiv\left(\mu, \alpha, \Psi_{i}, \Omega\right)$ can shift discretely from one regime to another (regimedependent). Such changes are considered as random events and governed by a Hidden Markov process. Then, these parameters are subject to latent discrete regime variables $S_{t} \in\{1, \cdots, m\}$, and then the MS-VECM model can be written as follows:

$$
\Delta Y_{t}=\mu\left(S_{t}\right)+\alpha\left(S_{t}\right) \beta^{\prime} Y_{t-1}+\sum_{i=1}^{p-1} \Psi_{i}\left(S_{t}\right) \Delta Y_{t-i}+\varepsilon_{t}
$$

which can be rewritten in the following matrix format:

$$
\Delta Y_{t}=\mu\left(S_{t}\right)+\Pi\left(S_{t}\right) Y_{t-1}+\Gamma(L)\left(S_{t}\right) \Delta Y_{t-1}+\varepsilon_{t}, t=1, \cdots, T
$$

where $\Delta$ denotes the difference operator, the $(2 \times 2)$ matrix lag polynomial $\Gamma(L)\left(S_{t}\right)$ of order $p$ denotes the state-dependent short-run dynamics of the model, $\varepsilon_{t} \operatorname{NID}\left(\mathbf{0}, \Omega\left(S_{t}\right)\right)$ is the innovation process with a regime-dependent variance-covariance matrix $\Omega\left(S_{t}\right)$ (i.e. a heteroscedastic error term). $S_{t}$ is an $m$-regime Markov process defined by constant transition probabilities:

$$
p_{i j}=\operatorname{Pr}\left(S_{t+1}=j \mid S_{t}=i\right), \sum_{j=1}^{m} p_{i j}=1 \forall i, j \in\{1, \cdots, m\}
$$

More precisely, $p_{i j}$ is the transition probability that both the real interest rate and gold prices changes are in regime $i$, given that the mast period they were in regime $j$. The transition probability $p_{i j}$ can be rewritten in the following matrix format:

$$
P=\left[\begin{array}{ccc}
p_{11} & \cdots & p_{1 m} \\
\vdots & \ddots & \vdots \\
p_{m 1} & \cdots & p_{m m}
\end{array}\right], \sum_{j=1}^{m} p_{i j}=1 \forall i, j \in\{1, \cdots, m\}
$$

The transition probabilities also provide us with the expected duration, $E\left(D_{j}\right)$, and the system is going to stay in a certain regime $^{2}$ :

$$
E\left(D_{j}\right)=\frac{1}{1-p_{j j}} \forall j \in\{1, \cdots, m\}
$$

The state-dependent long-run impact matrix $\Pi\left(S_{t}\right)=\alpha\left(S_{t}\right) \beta^{\prime}$ is defined by the $(r \times m)$ matrix of cointegrating vectors, $\beta^{\prime}$, and the $(m \times r)$ state-dependent weighting matrix, $\alpha\left(S_{t}\right)$ which contains the regime-dependent adjustment coefficients characterizing the reaction of each variable to disequilibria from the $r$ long-run relations given by the $r$-dimensional vector $\beta^{\prime} Y_{t-1}$. Switching in $\Pi\left(S_{t}\right)$ can be understood as switching in the cointegrating vectors, the state-dependent weighting matrix, or both. Such model can be interpreted as follows: the long-run relationship between the variables, $\beta^{\prime} Y_{t-1}$, is unchanging to the state of the economy; however, the weights given to each relationship, $\alpha\left(S_{t}\right)$, are state-dependent, which implies that the economy could probably have distinct long-run impacts across regimes via $\alpha\left(S_{t}\right)$, as long as keeping up any long-run relationship among the variables. More precisely, we can have the cointegrating relationship, $\beta^{\prime} Y_{t-1}$, while having different

\footnotetext{
1 For example, the previous studies about the presence of causality between spot and futures oil prices (Hammoudeh and Li, 2004; Bekiros and Diks, 2008) have concluded that the findings of Granger causality tests (presence and direction of causality) depend upon changes in the sample period.

2 When $p_{i j}$ is higher, then the null hypothesis of no regime shift would be rejected.
} 
long-run responses to shocks. Thus, switches can be interpreted as differences across regimes in the rate of long-run adjustment. In our study, a shock to the real interest rate, which may be caused by shifts in monetary policy, will have different long-run effects on gold prices.

In our analysis, we assume that the system of the real interest rate and gold prices is characterized by two regimes in their volatility, namely a larger mean, high-volatility regime and a smaller mean, low-volatility regime. Such assumption is supported by recession-expansion cycles detected in multiple financial and macroeconomic time series. This is in line with several studies showing that the two-state Markov switching model is adequate to describe the dynamic interaction between time series (Kanas and Tsiotas, 2005).

A useful starting point for building an appropriate MS-VECM model is to select the order $p$ by using the Bayesian information criterion (BIC) in a linear VAR $(p)$. In the next step of analysis, the Likelihood Ratio (LR) statistic is used to test the null hypothesis of non-linear MS-VECM against linear VCEM alternative. However, some elements of transition probabilities can take any values without influencing the likelihood function. This leads to both nuisance parameters and zero score problems, under the null hypothesis which implies that asymptotically the LR statistic fails to have a standard chi-square distribution. Therefore the LR needs to be adjusted or obtain an upper significance bound according to the suggestions by Davies. For circumventing the nuisance parameters problem, Ang and Bekaert (2002) suggest alternative LR tests for the case in which the statistic has the limit distribution of $\chi^{2}$ with $m$ degrees of freedom (the number of restriction plus the nuisance parameters). In the last step, given the non-linearity hypothesis, both the likelihood-ratio statistic and the Akaike information Criterion (AIC) are used to select the number of regimes and the MS specification.

The MS-VECM can be estimated using a two-step maximum likelihood procedure ${ }^{3}$. The first step consists of testing for the number of cointegrating relations $r$ (i.e., identify the rank of $\Pi\left(S_{t}\right)$ ) and estimating the coefficients of the $r$ cointegrating vectors in $\beta^{\prime}$ by using Johansen's (1988) maximum likelihood procedures. Then, conditional on these cointegrating vectors, the regime dependent adjustment parameters $\alpha\left(S_{t}\right)$, intercept terms $\mu\left(S_{t}\right)$, autoregressive coefficients $\Gamma(L)\left(S_{t}\right)$, and variance-covariance matrix $\Omega\left(S_{t}\right)$, as well as the transition probabilities are estimated by relying on a Markov Chain Monte Carlo (MCMC) methods, namely Gibbs sampling ${ }^{4}$. The Bayesian approach has two advantages that make it particularly attractive for the estimation of the MS-VECM model. First, the prior distribution for model parameters is often an advantage for Bayesian analysis of Markov switching models. Second, the Bayesian approach yields the transition probabilities which are not conditional on particular parameters values and, thus, these parameters are themselves assumed to be random variables.

\subsubsection{Prior distributions}

Let the vector $\theta$ contains the MS-VECM parameters $\left\{\mu_{i}\right\},\left\{\alpha_{i}\right\},\left\{\beta_{i}\right\},\left\{\Gamma_{i}\right\}$ and $\left\{\Omega_{i}\right\}, i=1, \cdots, m$ and the transition probabilities $\left\{p_{i j}\right\}, i, j=1, \cdots, m$. For the transition probabilities, we follow Chib and use beta priors:

$$
\begin{aligned}
& p_{i i} \operatorname{beta}\left(u_{i i}, u_{i j}\right) \\
& p_{j j} \operatorname{beta}\left(u_{j j}, u_{j i}\right)
\end{aligned}
$$

where beta refers to a beta distribution. For the variance-covariance matrix $\left\{\Omega_{i}\right\}$, we use the inverted Wishart distribution with $h$ degree of freedom as a prior:

$$
\Omega_{i} \operatorname{IW}\left(\Phi_{i}, h_{i}\right)
$$

where $\Phi_{i} \in I R^{2 \times 2}$. We consider the vector form $B_{i}=\left[\mu_{i}, \beta, \alpha_{i}, \Gamma_{i}^{\prime}\right]^{\prime}, i=1, \cdots, m$. As a prior for $B_{i}$, we use the multivariate normal:

$$
\operatorname{vec}\left(B_{i}\right) \operatorname{MN}\left(\mathbf{0}, \Sigma_{B_{i}}\right)
$$

multivariate normal with mean $\mathbf{0}$ and variance-covariance matrix $\Sigma_{B_{i}}$. After assuming that $\alpha_{i}, i=1, \cdots, m$, are independently distributed, then $\Sigma_{B_{i}}$ is defined as follows:

$$
\Sigma_{B_{i}}=\left[\begin{array}{cccc}
\Sigma_{\mu_{i}} & \mathbf{0} & \mathbf{0} & \mathbf{0} \\
\mathbf{0} & \Sigma_{\beta} & \mathbf{0} & \mathbf{0} \\
\mathbf{0} & \mathbf{0} & \Sigma_{\alpha_{i}} & \mathbf{0} \\
\mathbf{0} & \mathbf{0} & \mathbf{0} & \Sigma_{\Gamma_{\mathrm{i}}}
\end{array}\right]
$$

where $\Sigma_{\mu_{i}}, \Sigma_{\beta}, \Sigma_{\alpha_{i}}$ and $\Sigma_{\Gamma_{\mathrm{i}}}$ are priors for variance-covariance matrices of $\mu_{i}, \beta, \alpha_{i}$ and $\Gamma_{\mathrm{i}}$, respectively. We assume prior independence between $\Omega_{i}$ and $B_{i}$. We also assume the independence between the priors in the different regimes.

\footnotetext{
${ }^{3}$ This two-step procedure is due to Saikkonen (1992) who show that the Johansen procedure estimates are consistent cointegrating vectors even in the presence of switching.

${ }^{4}$ An alternative common used procedure is the expectation-maximization (EM) algorithm for maximum likelihood estimation. However, this approach, characterized by slow convergence, does not directly provide the posterior distribution of the parameters and estimates of the variance-covariance matrix of the errors.
} 


\subsubsection{Posteriori distributions}

Posteriors samples of all unknown parameters are drawn by using MCMC sampler as follows: First, we draw $\Omega_{i}, i=1, \cdots, m$ given regimes $S_{i}$, transition probabilities $P$ and the parameters $B_{i}$. The conditional posteriori of $\Omega_{i}$ is derived as an inverted Wishart distribution. Second, we draw regimes $S_{i}$ given transition probabilities $P$, the parameters $B_{i}$ and the variance matrix $\Omega_{i}, i=1, \cdots, m$ by using the multi-move Gibbs sampling algorithm. Finally, after drawing regimes, we generate the transition probabilities given the regimes. The unconditional transition probabilities are derived as a Dirichlet distribution. In the next step we apply the impulse response function (IRF) to analyze the dynamic interaction between real interest rate and gold price within each Markov switching regime.

\subsection{Data}

The analysis involves the G7 countries (US, UK, Germany, Canada, Japan, France, Italy), spanning the period 1975-2016. Quarterly data on gold prices (spot prices), real interest rates (nominal interest rates on 10-year government bonds have been gathered-to convert these rates to real rates, we subtracted the CPI inflation rate, percentage changes in the index), consumer prices indexes, real GDP (at 2005 prices), exchange rates with respect to the dollar (in the case of the European countries, prior to the euro era, the exchange rate was the ECU with respect to the dollar), oil prices (measured as spot prices for Cushing, OK WTI crude oil, measured in US dollars per barrel) silver prices (measured in dollar per troy ounce-spot prices), copper prices (measured in dollar per pound-spot prices) and stock price indexes (S\&P500, FTSE100, DAX, S\&P/TSX Comp, Nikkei225, CAC40, FTSE MIB) were obtained. All data are sourced from Datastream.

\section{Empirical analysis}

\subsection{Bivariate results}

In the first part of the analysis, a bivariate association is explored between real interest rates and gold prices. In particular, first we examine whether the data we use contain unit roots. Accordingly, we employ the standard efficient test proposed by Elliott et al. (1996). The test indicates that both series are characterized by non-stationarity (Table 1). The Elliot et al. (1996) test addresses the problem of the low power of the ADF test relative to local alternatives by using a GLS detrending procedure.

Table 2 reports the results of the cointegration rank tests. According to the cointegration rank tests, there exists a single cointegration vector. The finding of a single cointegrating vector strongly supports the presence of one common stochastic trend in the data set.

Next, normalising the cointegration vector against the gold prices, we obtain the unrestricted formulation of the long-run relationship. Hence, the long-run bivariate estimates are reported in Table 3. The findings illustrate a positive association between gold prices and real interest rates, with these estimates remaining consistently positive and statistically significant across all G7 countries. This positive association implies that tighter economic conditions in the most important countries around the globe seem to increase economic uncertainty, thus, leading to higher gold prices. Moreover, the higher impact is displayed in the case of the US, signifying the important role of US monetary policy for the domestic, as well as the global economic outlook. The findings of a positive association between gold prices and real interest rates gain support from certain studies in the literature (Cai et al., 2001; Batten et al., 2013). By contrast, Fortune (1987), Barsky and Summers (1988), Tulley and Lucey (2007) and Wang and Chueh (2013) highlight that real interest rates are negatively correlated with gold prices. Lawrence (2003) finds no statistical association between these two variables, while finally, Bhar and Hammoudeh (2011) claim that it is hard to find a sign association between them that dominates each other, because such an association is regime dependent (i.e., non-linear).

Table 1

Unit root tests.

\begin{tabular}{lll}
\hline \multirow{2}{*}{ Variables } & \multicolumn{2}{l}{ ADF-GLS test } \\
\cline { 2 - 3 } & Levels & First differences \\
\hline IrUS & -1.65 & $-6.13^{* * * *}$ \\
IrUK & -1.49 & $-5.93^{* * * *}$ \\
lrGermany & -1.45 & $-6.24^{* * *}$ \\
lrCanada & -1.57 & $-5.95^{* * *}$ \\
IrJapan & -1.48 & $-6.19^{* * *}$ \\
lrFrance & -1.63 & $-5.84^{* * *}$ \\
lrItaly & -1.68 & $-5.89^{* * *}$ \\
gp & -1.53 & $-6.26^{* * *}$ \\
\hline
\end{tabular}

gp denotes gold prices, while lr denotes longrun real interest rates.

p-value $\leq 0.01$. 
Table 2

Johansen's cointegration tests.

\begin{tabular}{|c|c|c|c|c|c|}
\hline Null & Alternative & Eigenvalue & Critical & Trace & Critical \\
\hline \multicolumn{6}{|l|}{ US } \\
\hline$r=0$ & $r \leq 1$ & 39.8725 & 34.1200 & 59.8636 & 43.2300 \\
\hline$r=1$ & $r \leq 2$ & 2.8184 & 3.5600 & 2.8184 & 3.5600 \\
\hline \multicolumn{6}{|l|}{ UK } \\
\hline$r=0$ & $r \leq 1$ & 37.6471 & 34.1200 & 55.6094 & 43.2300 \\
\hline$r=1$ & $r \leq 2$ & 1.4115 & 3.5600 & 1.4115 & 3.5600 \\
\hline \multicolumn{6}{|c|}{ Germany } \\
\hline$r=0$ & $\mathrm{r} \leq 1$ & 43.5116 & 34.1200 & 68.3055 & 43.2300 \\
\hline$r=1$ & $\mathrm{r} \leq 2$ & 2.0456 & 3.5600 & 2.0456 & 3.5600 \\
\hline \multicolumn{6}{|c|}{ Canada } \\
\hline$r=0$ & $\mathrm{r} \leq 1$ & 40.0073 & 34.1200 & 63.8057 & 43.2300 \\
\hline$r=1$ & $r \leq 2$ & 1.9431 & 3.5600 & 1.9431 & 3.5600 \\
\hline \multicolumn{6}{|c|}{ Japan } \\
\hline$r=0$ & $r \leq 1$ & 36.5113 & 34.1200 & 51.0198 & 43.2300 \\
\hline \multirow{2}{*}{\multicolumn{6}{|c|}{ France }} \\
\hline & & & & & \\
\hline$r=0$ & $r \leq 1$ & 48.1927 & 34.1200 & 65.9942 & 43.2300 \\
\hline$r=1$ & $r \leq 2$ & 1.3562 & 3.5600 & 1.3562 & 3.5600 \\
\hline \multicolumn{6}{|l|}{ Italy } \\
\hline$r=0$ & $\mathrm{r} \leq 1$ & 41.5014 & 34.1200 & 53.2428 & 43.2300 \\
\hline$r=1$ & $r \leq 2$ & 0.9673 & 3.5600 & 0.9673 & 3.5600 \\
\hline
\end{tabular}

Null and alternative denote the null and alternative hypothesis, respectively. $r$ denotes the number of cointegrating vectors.

Table 3

Cointegrating bivariate vectors from Johansen estimation between gold prices and real interest rates.

\begin{tabular}{llll}
\hline Variables & Coefficient & p-value & $\mathrm{R}^{2}$-adjusted \\
\hline US & & & \\
constant & 0.885 & 0.04 & 0.35 \\
lr & 0.316 & 0.00 & \\
UK & & & \\
constant & 0.975 & 0.03 & 0.28 \\
lr & 0.234 & 0.00 & \\
Germany & & & \\
constant & 0.919 & 0.05 & 0.29 \\
lr & 0.268 & 0.00 & \\
Canada & & & \\
constant & 0.977 & 0.04 & 0.26 \\
lr & 0.188 & 0.01 & \\
Japan & & & \\
constant & 1.019 & 0.01 & 0.22 \\
lr & 0.203 & 0.01 & \\
France & & & \\
constant & 1.336 & 0.00 & 0.17 \\
lr & 0.125 & 0.02 & \\
Italy & & 0.00 & \\
constant & 1.637 & 0.04 & \\
lr & 0.109 & & \\
\hline
\end{tabular}

Next, we turn to the investigation of the short-run dynamics of the system both in relation to the adjustment towards the long-run equilibrium and the direct linkages across the underlying markets, as described by the interactions between the lagged variables in the underlying VECM. After establishing a cointegrating relationship between gold prices and real interest rates, linear VECM and different variants of MS-VECM are estimated. The tests based on information criterion are used to determine the number of regimes. Table 4 shows the comparison of linear VECM and different specifications of nonlinear MS-VECM based on the Akaike information criterion (AIC). According to the AIC criterion, the best model specification is a non-linear specification for the US, the UK, Italy and Germany, being an MS(3)-VECM(1,1) model, with three regimes, heteroscedastic errors and an autoregressive order of one. For Canada, the best model specification is also a non-linear specification, that is a MS (3)-VECM $(2,2)$ model. However, for the case of Japan and France in which the VECM model goes with two lags, we accept the "linear" null. Therefore, linear VECM is selected for estimating the gold price response to real interest rate changes and conclude that there is weak evidence in favor of the cases of two and three regimes.

The results on non-linear estimates are reported in Table 5. The first regime is the one characterized by a booming economy, while conversely, the second regime presents recessionary periods, including the period of the recent sub-prime crisis, 
Table 4

Information criterion of VECM and MS-VECM of gold prices and real interest rates (the multivariate model).

\begin{tabular}{|c|c|}
\hline Model & AIC \\
\hline \multicolumn{2}{|l|}{ US } \\
\hline $\operatorname{VECM}(1,1)$ & -537.81 \\
\hline $\operatorname{VECM}(2,2)$ & -557.42 \\
\hline $\operatorname{MS}(2)-\operatorname{VECM}(1,1)$ & -508.93 \\
\hline $\operatorname{MS}(2)-\operatorname{VECM}(2,2)$ & -567.35 \\
\hline MS(3)-VECM(1,1) & -603.44 \\
\hline MS(3)-VECM(2,2) & -593.28 \\
\hline \multicolumn{2}{|l|}{ UK } \\
\hline $\operatorname{VECM}(1,1)$ & -575.16 \\
\hline $\operatorname{VECM}(2,2)$ & -610.28 \\
\hline MS(2)-VECM(1,1) & -525.44 \\
\hline $\operatorname{MS}(2)-\operatorname{VECM}(2,2)$ & -589.06 \\
\hline $\operatorname{MS}(3)-\operatorname{VECM}(1,1)$ & -637.29 \\
\hline $\operatorname{MS}(3)-\operatorname{VECM}(2,2)$ & -610.75 \\
\hline \multicolumn{2}{|l|}{ Germany } \\
\hline $\operatorname{VECM}(1,1)$ & -552.32 \\
\hline $\operatorname{VECM}(2,2)$ & -598.03 \\
\hline $\operatorname{MS}(2)-\operatorname{VECM}(1,1)$ & -527.49 \\
\hline $\operatorname{MS}(2)-\operatorname{VECM}(2,2)$ & -586.54 \\
\hline $\operatorname{MS}(3)-\operatorname{VECM}(1,1)$ & -642.51 \\
\hline MS(3)-VECM(2,2) & -619.85 \\
\hline \multicolumn{2}{|l|}{ Canada } \\
\hline $\operatorname{VECM}(1,1)$ & -511.29 \\
\hline $\operatorname{VECM}(2,2)$ & -548.25 \\
\hline $\operatorname{MS}(2)-\operatorname{VECM}(1,1)$ & -486.35 \\
\hline $\operatorname{MS}(2)-\operatorname{VECM}(2,2)$ & -526.49 \\
\hline $\operatorname{MS}(3)-\operatorname{VECM}(1,1)$ & -558.07 \\
\hline $\operatorname{MS}(3)-\operatorname{VECM}(2,2)$ & -574.85 \\
\hline \multicolumn{2}{|l|}{ Japan } \\
\hline $\operatorname{VECM}(1,1)$ & -595.63 \\
\hline \multicolumn{2}{|l|}{ Model AIC } \\
\hline $\operatorname{VECM}(2,2)$ & -631.20 \\
\hline $\operatorname{MS}(2)-\operatorname{VECM}(1,1)$ & -584.48 \\
\hline $\operatorname{MS}(2)-\operatorname{VECM}(2,2)$ & -561.52 \\
\hline $\operatorname{MS}(3)-\operatorname{VECM}(1,1)$ & -629.05 \\
\hline MS(3)-VECM(2,2) & -588.74 \\
\hline \multicolumn{2}{|l|}{ France } \\
\hline $\operatorname{VECM}(1,1)$ & -591.14 \\
\hline $\operatorname{VECM}(2,2)$ & -632.02 \\
\hline MS(2)-VECM(1,1) & -566.35 \\
\hline $\operatorname{MS}(2)-\operatorname{VECM}(2,2)$ & -594.61 \\
\hline $\operatorname{MS}(3)-\operatorname{VECM}(1,1)$ & -640.32 \\
\hline $\operatorname{MS}(3)-\operatorname{VECM}(2,2)$ & -622.51 \\
\hline \multicolumn{2}{|l|}{ Italy } \\
\hline $\operatorname{VECM}(1,1)$ & -584.92 \\
\hline $\operatorname{VECM}(2,2)$ & -609.36 \\
\hline $\operatorname{MS}(2)-\operatorname{VECM}(1,1)$ & -547.52 \\
\hline $\operatorname{MS}(2)-\operatorname{VECM}(2,2)$ & -595.53 \\
\hline $\operatorname{MS}(3)-\operatorname{VECM}(1,1)$ & -629.30 \\
\hline MS(3)-VECM(2,2) & -604.81 \\
\hline
\end{tabular}

from 2007q4 to 2009q2. For the case of the US economy, the ergodic probability and transition matrices suggest the dominance of the first regime. In particular, the first regime persists for 61.14 percent of the quarters and lasts for 116 quarters, while the second regime remains for 38.60 percent of the quarters, lasting for 52 quarters. The results match those on the US turning points of the business cycle revealed by the NBER. Moreover, although both regimes support the adjustment of gold prices towards long-run equilibrium, this primarily occurs over the second regime, implying that gold prices adjust faster during recessions; in that sense, gold prices display a strong hedging potential during recessionary times. At the same time, there exists a negative and significant relationship between the change in the lagged value of real interest rates and the change in the lagged value of gold prices in both regimes, with the impact being stronger in the second regime (the recessionary phase). Overall, we can conclude that gold prices can provide hedging services against real interest rate movements mainly during recessionary times. The results for the remaining six economies remain persistently similar, with the findings matching the turning business cycle points published by the CD Howe Institute Business Cycle Council for Canada, CEPR for the three European (and Eurozone) economies, Investing.com for the UK, and the Research Economic Outlook of the FRB of Saint Louis for Japan. 
Table 5

Bivariate results of the non-linear model for gold prices and real interest rates.

\begin{tabular}{|c|c|c|c|c|c|}
\hline & & \multicolumn{2}{|l|}{ Regime 1} & \multicolumn{2}{|l|}{ Regime 2} \\
\hline & & $\Delta \mathrm{gp}$ & $\Delta \mathrm{lr}$ & $\Delta \mathrm{gp}$ & $\Delta \mathrm{lr}$ \\
\hline \multicolumn{6}{|l|}{ US } \\
\hline Intercept & & $0.784[0.02]$ & $0.649[0.04]$ & $1.562[0.01]$ & $1.883[0.00]$ \\
\hline$\Delta g p(-1)$ & & $0.262[0.01]$ & $0.083[0.07]$ & $0.581[0.00]$ & $0.156[0.01]$ \\
\hline$\Delta \operatorname{lr}(-1)$ & & $0.096[0.01]$ & $0.105[0.01]$ & $0.485[0.00]$ & $0.613[0.00]$ \\
\hline Error correction & & $-0.089[0.01]$ & $-0.094[0.01]$ & $-0.182[0.00]$ & $-0.196[0.00]$ \\
\hline \multicolumn{6}{|c|}{ Variance-Covariance matrix } \\
\hline$\Delta \mathrm{gp}$ & & $0.00177[0.00]$ & $0.00031[0.18]$ & $0.00216[0.00]$ & $0.00047[0.15]$ \\
\hline$\Delta \mathrm{lr}$ & & $0.00082[0.12]$ & $0.00214[0.00]$ & $0.00063[0.12]$ & $0.00274[0.00]$ \\
\hline \multicolumn{6}{|l|}{ Transition matrix } \\
\hline & Regime 1 & Regime 2 & Obs. & Ergodic probability & Duration \\
\hline Regime 1 & 0.264 & 0.201 & 118.6 & 0.614 & 116 \\
\hline Regime 2 & 0.179 & 0.571 & 41.2 & 0.386 & 52 \\
\hline \multicolumn{6}{|l|}{ UK } \\
\hline Intercept & & $0.949[0.01]$ & $0.486[0.05]$ & $1.529[0.00]$ & $1.448[0.00]$ \\
\hline$\Delta g p(-1)$ & & $0.241[0.01]$ & $0.065[0.08]$ & $0.526[0.00]$ & $0.139[0.01]$ \\
\hline$\Delta \operatorname{lr}(-1)$ & & $0.087[0.01]$ & $0.181[0.01]$ & $0.457[0.00]$ & $0.586[0.00]$ \\
\hline Error correction & & $-0.073[0.01]$ & $-0.088[0.01]$ & $-0.149[0.00]$ & $-0.168[0.00]$ \\
\hline \multicolumn{6}{|c|}{ Variance-Covariance matrix } \\
\hline$\Delta g p$ & & $0.00154[0.00]$ & $0.00025[0.23]$ & $0.00203[0.00]$ & $0.00041[0.19]$ \\
\hline$\Delta \mathrm{lr}$ & & $0.00067[0.19]$ & $0.00183[0.01]$ & $0.00048[0.20]$ & $0.00238[0.00]$ \\
\hline \multicolumn{6}{|l|}{ Transition matrix } \\
\hline & Regime 1 & Regime 2 & Obs. & Ergodic probability & Duration \\
\hline Regime 1 & 0.233 & 0.179 & 103.4 & 0.752 & 104 \\
\hline Regime 2 & 0.153 & 0.518 & 62.1 & 0.248 & 64 \\
\hline \multicolumn{6}{|l|}{ Germany } \\
\hline Intercept & & $0.985[0.00]$ & $0.502[0.04]$ & $1.611[0.00]$ & $1.479[0.00]$ \\
\hline$\Delta \mathrm{gp}(-1)$ & & $0.266[0.01]$ & $0.073[0.07]$ & $0.548[0.00]$ & $0.145[0.01]$ \\
\hline$\Delta \operatorname{lr}(-1)$ & & $0.092[0.01]$ & $0.196[0.00]$ & $0.472[0.00]$ & $0.601[0.00]$ \\
\hline Error correction & & $-0.079[0.01]$ & $-0.095[0.01]$ & $-0.158[0.00]$ & $-0.181[0.00]$ \\
\hline \multicolumn{6}{|c|}{ Variance-Covariance matrix } \\
\hline$\Delta \mathrm{gp}$ & & $0.00168[0.00]$ & $0.00032[0.21]$ & $0.00235[0.00]$ & $0.00049[0.16]$ \\
\hline$\Delta \mathrm{lr}$ & & $0.00078[0.16]$ & $0.00199[0.01]$ & $0.00064[0.17]$ & $0.00260[0.00]$ \\
\hline \multicolumn{6}{|l|}{ Transition matrix } \\
\hline & Regime 1 & Regime 2 & Obs. & Ergodic probability & Duration \\
\hline Regime 1 & 0.250 & 0.186 & 76.8 & 0.729 & 104 \\
\hline Regime 2 & 0.159 & 0.531 & 90.2 & 0.271 & 10 \\
\hline \multicolumn{6}{|l|}{ Canada } \\
\hline Intercept & & $0.914[0.00]$ & $0.517[0.03]$ & $1.563[0.00]$ & $1.493[0.00]$ \\
\hline$\Delta g p(-1)$ & & $0.248[0.01]$ & $0.067[0.08]$ & $0.526[0.00]$ & $0.132[0.01]$ \\
\hline$\Delta \operatorname{lr}(-1)$ & & $0.076[0.02]$ & $0.173[0.00]$ & $0.458[0.00]$ & $0.574[0.00]$ \\
\hline Error correction & & $-0.072[0.01]$ & $-0.089[0.01]$ & $-0.144[0.00]$ & $-0.166[0.00]$ \\
\hline \multicolumn{6}{|c|}{ Variance-Covariance matrix } \\
\hline$\Delta \mathrm{gp}$ & & $0.00161[0.00]$ & $0.00030[0.22]$ & $0.00219[0.00]$ & $0.00045[0.18]$ \\
\hline$\Delta \mathrm{lr}$ & & $0.00072[0.17]$ & $0.00186[0.01]$ & $0.00060[0.19]$ & $0.00246[0.00]$ \\
\hline \multicolumn{6}{|l|}{ Transition matrix } \\
\hline & Regime 1 & Regime 2 & Obs. & Ergodic probability & Duration \\
\hline Regime 1 & 0.244 & 0.180 & 78.4 & 0.691 & 143 \\
\hline Regime 2 & 0.151 & 0.516 & 89.0 & 0.309 & 25 \\
\hline \multicolumn{6}{|l|}{ Japan } \\
\hline Intercept & & $1.042[0.00]$ & $0.784[0.02]$ & $1.326[0.00]$ & $1.547[0.00]$ \\
\hline$\Delta \mathrm{gp}(-1)$ & & $0.199[0.01]$ & $0.062[0.08]$ & $0.585[0.00]$ & $0.152[0.01]$ \\
\hline$\Delta \operatorname{lr}(-1)$ & & $0.075[0.02]$ & $0.144[0.00]$ & $0.489[0.00]$ & $0.599[0.00]$ \\
\hline Error correction & & $-0.061[0.01]$ & $-0.083[0.01]$ & $-0.168[0.00]$ & $-0.182[0.00]$ \\
\hline
\end{tabular}


Table 5 (continued)

\begin{tabular}{|c|c|c|c|c|c|}
\hline & & \multicolumn{2}{|l|}{ Regime 1} & \multicolumn{2}{|l|}{ Regime 2} \\
\hline & & $\Delta \mathrm{gp}$ & $\Delta \mathrm{lr}$ & $\Delta \mathrm{gp}$ & $\Delta \mathrm{lr}$ \\
\hline $\begin{array}{l}\text { Variance-Covariar } \\
\Delta \mathrm{gp} \\
\Delta \mathrm{lr}\end{array}$ & & $\begin{array}{l}0.00194[0.00] \\
0.00093[0.13]\end{array}$ & $\begin{array}{l}0.00048[0.19] \\
0.00202[0.00]\end{array}$ & $\begin{array}{l}0.00245[0.00] \\
0.00073[0.16]\end{array}$ & $\begin{array}{l}0.00061[0.15] \\
0.00282[0.00]\end{array}$ \\
\hline \multicolumn{6}{|l|}{ Transition matrix } \\
\hline & Regime 1 & Regime 2 & Obs. & Ergodic probability & Duration \\
\hline $\begin{array}{l}\text { Regime } 1 \\
\text { Regime } 2\end{array}$ & $\begin{array}{l}0.273 \\
0.160\end{array}$ & $\begin{array}{l}0.198 \\
0.563\end{array}$ & $\begin{array}{l}61.2 \\
106.9\end{array}$ & $\begin{array}{l}0.328 \\
0.672\end{array}$ & $\begin{array}{l}67 \\
101\end{array}$ \\
\hline $\begin{array}{l}\text { France } \\
\text { Intercept } \\
\Delta \mathrm{gp}(-1) \\
\Delta \operatorname{lr}(-1) \\
\text { Error correction }\end{array}$ & & $\begin{array}{l}0.814[0.00] \\
0.228[0.01] \\
0.058[0.04] \\
-0.071[0.01]\end{array}$ & $\begin{array}{l}0.429[0.05] \\
0.064[0.08] \\
0.164[0.00] \\
-0.080[0.01]\end{array}$ & $\begin{array}{l}1.438[0.00] \\
0.521[0.00] \\
0.448[0.00] \\
-0.135[0.00]\end{array}$ & $\begin{array}{l}1.425[0.00] \\
0.119[0.01] \\
0.463[0.00] \\
-0.155[0.00]\end{array}$ \\
\hline $\begin{array}{l}\text { Variance-Covariar } \\
\Delta \mathrm{gp} \\
\Delta \mathrm{lr}\end{array}$ & & $\begin{array}{l}0.00146[0.00] \\
0.00066[0.20]\end{array}$ & $\begin{array}{l}0.00026[0.24] \\
0.00174[0.01]\end{array}$ & $\begin{array}{l}0.00218[0.00] \\
0.00052[0.23]\end{array}$ & $\begin{array}{l}0.00042[0.22] \\
0.00226[0.00]\end{array}$ \\
\hline \multicolumn{6}{|l|}{ Transition matrix } \\
\hline & Regime 1 & Regime 2 & Obs. & Ergodic probability & Duration \\
\hline Regime 2 & $\begin{array}{l}0.228 \\
0.148\end{array}$ & $\begin{array}{l}0.163 \\
0.504 \\
\text { Regime 1 } \\
\Delta \mathrm{gp}\end{array}$ & $\begin{array}{l}76.2 \\
89.6 \\
\Delta \mathrm{lr}\end{array}$ & $\begin{array}{l}0.702 \\
0.298 \\
\text { Regime } 2 \\
\Delta \mathrm{gp}\end{array}$ & $\begin{array}{l}104 \\
10 \\
\Delta \mathrm{lr}\end{array}$ \\
\hline $\begin{array}{l}\text { Italy } \\
\text { Intercept } \\
\Delta \mathrm{gp}(-1) \\
\Delta \operatorname{lr}(-1) \\
\text { Error correction }\end{array}$ & & $\begin{array}{l}0.763[0.01] \\
0.204[0.01] \\
0.051[0.05] \\
-0.059[0.02]\end{array}$ & $\begin{array}{l}0.410[0.05] \\
0.055[0.09] \\
0.132[0.02] \\
-0.071[0.01]\end{array}$ & $\begin{array}{l}1.384[0.00] \\
0.496[0.01] \\
0.419[0.00] \\
-0.118[0.01]\end{array}$ & $\begin{array}{l}1.379[0.01] \\
0.102[0.01] \\
0.437[0.00] \\
-0.132[0.00]\end{array}$ \\
\hline $\begin{array}{l}\text { Variance-Covariar } \\
\Delta \mathrm{gp} \\
\Delta \mathrm{lr}\end{array}$ & & $\begin{array}{l}0.00129[0.00] \\
0.00050[0.22]\end{array}$ & $\begin{array}{l}0.00021[0.27] \\
0.00153[0.01]\end{array}$ & $\begin{array}{l}0.00201[0.01] \\
0.00044[0.26]\end{array}$ & $\begin{array}{l}0.00037[0.23] \\
0.00211[0.00]\end{array}$ \\
\hline \multicolumn{6}{|l|}{ Transition matrix } \\
\hline & Regime 1 & Regime 2 & Obs. & Ergodic probability & Duration \\
\hline $\begin{array}{l}\text { Regime } 1 \\
\text { Regime } 2\end{array}$ & $\begin{array}{l}0.214 \\
0.133\end{array}$ & $\begin{array}{l}0.141 \\
0.479\end{array}$ & $\begin{array}{l}76.8 \\
90.1\end{array}$ & $\begin{array}{l}0.681 \\
0.319\end{array}$ & $\begin{array}{l}104 \\
10\end{array}$ \\
\hline
\end{tabular}

Figures in brackets denote p-values.

\subsection{Robustness check}

This part of the empirical analysis extends the bivariate version of our modeling approach by including more drivers for gold prices, including consumer prices (Cecchetti et al., 2000; Boivin and Ng, 2006; Banerjee and Marcellino, 2006; Dempster and Artigas, 2009), real GDP (at 2005 prices) (Martha and Tran, 2007; Bapna et al., 2012; Warda et al., 2014), exchange rates (Kiohos and Sariannidis, 2010; Apak et al., 2012), oil prices (Wang et al., 2010; Samanta and Zadeh, 2012), silver prices (Aggarwal et al., 2014; Ciner, 2015), copper prices (Roache and Rossi, 2009) and stock prices (Baur and Lucey, 2010; Baur and McDermott, 2010; Gaur and Bansal, 2010). We first examine whether the new drivers contain unit roots. The Elliott et al. (1996) test indicates that all series are characterized by non-stationarity (Table 6).

Next, given the stationarity tests reported in Table 6, the new cointegration findings (available upon request) document the presence of cointegration across the expanded model, as well as the presence of a single cointegration vector. Normalising the cointegration vector against the gold prices, we obtain the formulation of the long-run relationship, with the longrun multivariate estimates being reported in Table 7. The new findings illustrate a positive association between gold prices and real interest rates, with these estimates remaining consistently positive and statistically significant across all G7 countries. The higher impact is displayed (once again) in the case of the US, signifying the important role of US monetary policy for the domestic, as well as the global economic outlook. In terms of the alternative asset investments, the impact of stock, silver and copper prices is negative across all seven economies indicating the competitive portfolio role of those assets against gold prices. By contrast, oil prices exert a positive effect on gold prices, exemplifying the role of oil for inflationary pressures. Finally, inflation has a positive impact on gold prices, implying the higher uncertainty associated with inflation rates, while the effect of income on gold prices is also positive, indicating a kind of wealth effect for gold prices. 
Table 6

Unit root tests (new drivers).

\begin{tabular}{|c|c|c|}
\hline \multirow[t]{2}{*}{ Variables } & \multicolumn{2}{|c|}{ ADF-GLS test } \\
\hline & Levels & First differences \\
\hline Oil prices & -1.26 & $-6.38^{* * *}$ \\
\hline Silver prices & -1.38 & $-6.42^{* * *}$ \\
\hline Copper prices & -1.44 & $-6.36^{* * *}$ \\
\hline $\mathrm{e}($ pound $/ \$)$ & -1.61 & $-5.95^{* * *}$ \\
\hline $\mathrm{e}($ euro/\$) & -1.44 & $-5.98^{* * *}$ \\
\hline $\mathrm{e}($ Can $\$ / \$)$ & -1.39 & $-6.41^{* * *}$ \\
\hline $\mathrm{e}($ yen $/ \$)$ & -1.42 & $-6.17^{* * *}$ \\
\hline yUS & -1.27 & $-6.35^{* * *}$ \\
\hline yUK & -1.30 & $-6.11^{* * *}$ \\
\hline yGermany & -1.25 & $-6.19^{* * *}$ \\
\hline yCanada & -1.32 & $-6.35^{* * *}$ \\
\hline yJapan & -1.45 & $-6.24^{* * *}$ \\
\hline yFrance & -1.59 & $-5.91^{* * *}$ \\
\hline yItaly & -1.62 & $-6.06^{* * *}$ \\
\hline pUS & -1.37 & $-6.31^{* * *}$ \\
\hline pUK & -1.42 & $-5.94^{* * *}$ \\
\hline pGermany & -1.38 & $-6.13^{* * *}$ \\
\hline pCanada & -1.47 & $-5.86^{* * *}$ \\
\hline pJapan & -1.56 & $-5.52^{* * * *}$ \\
\hline pFrance & -1.41 & $-5.93^{* * *}$ \\
\hline pItaly & -1.39 & $-6.09^{* * * *}$ \\
\hline spUS & -1.26 & $-6.52^{* * *}$ \\
\hline spUK & -1.39 & $-6.30^{* * *}$ \\
\hline spGermany & -1.32 & $-6.48^{* * *}$ \\
\hline spCanada & -1.47 & $-6.22^{* * *}$ \\
\hline spJapan & -1.54 & $-5.67^{* * *}$ \\
\hline spFrance & -1.38 & $-5.89^{* * *}$ \\
\hline spItaly & -1.46 & $-5.74^{* * *}$ \\
\hline
\end{tabular}

e, y, p and sp denote exchange rate, real income, consumer prices and stock prices, respectively.

p-value $\leq 0.01$

Next, we again investigate the short-run dynamics of the system both in relation to the adjustment towards the long-run equilibrium and the direct linkages across the underlying markets, as described by the interactions between the lagged variables in the underlying VECM. Once again, linear VECM and different variants of MS-VECM are estimated, with the results being reported in Table 8, which shows the comparison of linear VECM and different specifications of non-linear MS-VECM based on the Akaike information criterion (AIC). The multivariate results illustrate that the best model specification for Germany, Canada, Japan, France and Italy is a non-linear specification, that is a $\operatorname{MS}(3)-\operatorname{VECM}(2,2)$ model, with three regimes, heteroscedastic errors and an autoregressive order of two. However, for the case of the US, we accept the null hypothesis which correspond to a linear VECM with one lag.

The multivariate results on non-linear estimates are reported in Table 9. For the sake of brevity only the results on the EC terms, as well as on the transition matrix per regime are reported (the detailed results are available upon request). Across all seven cases, the ergodic probability and transition matrices recommend the dominant role of the first regime. Once again, both regimes illustrate the presence of a substantial adjustment of gold prices towards long-run equilibrium, which gets stronger in the second regime, implying that gold prices adjust faster during recessions; in that sense, gold prices display a strong hedging behavior during recessions. The negative and significant relationship between the change in the lagged value of real interest rates and the change in the lagged value of gold prices remains in both regimes, with the impact being stronger in the recessionary regime. Overall, even in the multivariate case, we can definitely conclude that gold prices provide hedging services against real interest rate movements, primarily during recessions.

\section{Conclusion}

In this paper we examine the relationship between interest rates and gold prices using a Bayesian Markov-Switching Vector Error-Correction (MS-VECM) model, along with regime-dependent impulse response functions, spanning the period 1975 to 2016. A MS(2)-VECM(1,1), with two regimes, heteroscedastic errors and an autoregressive order of one is selected according to the AIC. The first regime is one characterized by a booming economy, while the second regime presents recessionary periods, including the period of the recent sub-prime crisis, from 2007q4 to 2009q2. The findings suggest a positive association between gold prices and real interest rates across all G7 countries. A higher impact is shown in the case of the US, signifying the important role of US monetary policy for domestic, as well as the global economy. There also exists a negative and 
Table 7

Cointegrating multivariate vectors.

\begin{tabular}{|c|c|c|c|}
\hline Variables & Coefficient & p-value & $\mathrm{R}^{2}$-adjusted \\
\hline \multicolumn{4}{|l|}{ US } \\
\hline constant & 0.562 & 0.08 & 0.67 \\
\hline $\mathrm{lr}$ & 0.297 & 0.00 & \\
\hline oil prices & 0.214 & 0.00 & \\
\hline silver prices & -0.156 & 0.00 & \\
\hline copper prices & -0.118 & 0.01 & \\
\hline $\mathrm{y}$ & 0.439 & 0.00 & \\
\hline $\mathrm{p}$ & 0.327 & 0.00 & \\
\hline sp & -0.239 & 0.00 & \\
\hline \multicolumn{4}{|l|}{ UK } \\
\hline constant & 0.619 & 0.06 & 0.61 \\
\hline $\operatorname{lr}$ & 0.273 & 0.00 & \\
\hline oil prices & 0.211 & 0.00 & \\
\hline silver prices & -0.149 & 0.00 & \\
\hline copper prices & -0.126 & 0.00 & \\
\hline$e^{r t}$ & 0.235 & 0.00 & \\
\hline $\mathrm{y}$ & 0.384 & 0.00 & \\
\hline $\mathrm{p}$ & 0.308 & 0.00 & \\
\hline sp & -0.220 & 0.00 & \\
\hline \multicolumn{4}{|l|}{ Germany } \\
\hline constant & 0.517 & 0.08 & 0.68 \\
\hline $\mathrm{lr}$ & 0.298 & 0.00 & \\
\hline oil prices & 0.264 & 0.00 & \\
\hline silver prices & -0.162 & 0.00 & \\
\hline copper prices & -0.143 & 0.00 & \\
\hline$e^{r t}$ & 0.274 & 0.00 & \\
\hline $\mathrm{y}$ & 0.415 & 0.00 & \\
\hline $\mathrm{p}$ & 0.337 & 0.00 & \\
\hline sp & -0.243 & 0.00 & \\
\hline \multicolumn{4}{|l|}{ Canada } \\
\hline constant & 0.566 & 0.08 & 0.63 \\
\hline $\operatorname{lr}$ & 0.266 & 0.00 & \\
\hline oil prices & 0.249 & 0.00 & \\
\hline silver prices & -0.135 & 0.00 & \\
\hline copper prices & -0.116 & 0.00 & \\
\hline e & 0.225 & 0.00 & \\
\hline $\mathrm{y}$ & 0.377 & 0.00 & \\
\hline $\mathrm{p}$ & 0.294 & 0.00 & \\
\hline sp & -0.201 & 0.00 & \\
\hline \multicolumn{4}{|l|}{ Japan } \\
\hline constant & 0.613 & 0.07 & 0.65 \\
\hline $\operatorname{lr}$ & 0.285 & 0.00 & \\
\hline oil prices & 0.261 & 0.00 & \\
\hline silver prices & -0.108 & 0.01 & \\
\hline copper prices & -0.084 & 0.03 & \\
\hline 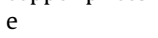 & 0.257 & 0.00 & \\
\hline $\mathrm{y}$ & 0.318 & 0.00 & \\
\hline $\mathrm{p}$ & 0.152 & 0.00 & \\
\hline sp & -0.269 & 0.00 & \\
\hline \multicolumn{4}{|l|}{ France } \\
\hline constant & 0.598 & 0.06 & 0.62 \\
\hline $\mathrm{lr}$ & 0.279 & 0.00 & \\
\hline oil prices & 0.235 & 0.00 & \\
\hline silver prices & -0.134 & 0.00 & \\
\hline copper prices & -0.092 & 0.00 & \\
\hline $\mathrm{e}$ & 0.271 & 0.00 & \\
\hline $\mathrm{y}$ & 0.368 & 0.00 & \\
\hline $\mathrm{p}$ & 0.314 & 0.00 & \\
\hline sp & -0.212 & 0.00 & \\
\hline \multicolumn{4}{|l|}{ Italy } \\
\hline constant & 0.654 & 0.05 & 0.59 \\
\hline $\operatorname{lr}$ & 0.252 & 0.00 & \\
\hline oil prices & 0.229 & 0.00 & \\
\hline silver prices & -0.116 & 0.00 & \\
\hline copper prices & -0.086 & 0.00 & \\
\hline e & 0.274 & 0.00 & \\
\hline $\mathrm{y}$ & 0.344 & 0.00 & \\
\hline $\mathrm{p}$ & 0.338 & 0.00 & \\
\hline sp & -0.185 & 0.00 & \\
\hline
\end{tabular}


Table 8

Information criterion of VECM and MS-VECM of gold prices and real interest rates.

\begin{tabular}{|c|c|}
\hline Model & AIC \\
\hline \multicolumn{2}{|l|}{ US } \\
\hline $\operatorname{VECM}(1,1)$ & -614.25 \\
\hline $\operatorname{VECM}(2,2)$ & -609.39 \\
\hline $\operatorname{MS}(2)-\operatorname{VECM}(1,1)$ & -546.41 \\
\hline $\operatorname{MS}(2)-\operatorname{VECM}(2,2)$ & -575.82 \\
\hline $\operatorname{MS}(3)-\operatorname{VECM}(1,1)$ & -584.37 \\
\hline $\operatorname{MS}(3)-\operatorname{VECM}(2,2)$ & -600.74 \\
\hline \multicolumn{2}{|l|}{ UK } \\
\hline $\operatorname{VECM}(1,1)$ & -598.72 \\
\hline $\operatorname{VECM}(2,2)$ & -615.59 \\
\hline $\operatorname{MS}(2)-\operatorname{VECM}(1,1)$ & -561.09 \\
\hline $\operatorname{MS}(2)-\operatorname{VECM}(2,2)$ & -599.75 \\
\hline $\operatorname{MS}(3)-\operatorname{VECM}(1,1)$ & -625.61 \\
\hline $\operatorname{MS}(3)-\operatorname{VECM}(2,2)$ & -649.11 \\
\hline \multicolumn{2}{|l|}{ Germany } \\
\hline $\operatorname{VECM}(1,1)$ & -598.45 \\
\hline $\operatorname{VECM}(2,2)$ & -614.92 \\
\hline $\operatorname{MS}(2)-\operatorname{VECM}(1,1)$ & -576.14 \\
\hline $\operatorname{MS}(2)-\operatorname{VECM}(2,2)$ & -596.53 \\
\hline $\operatorname{MS}(3)-\operatorname{VECM}(1,1)$ & -626.29 \\
\hline $\operatorname{MS}(3)-\operatorname{VECM}(2,2)$ & -652.34 \\
\hline \multicolumn{2}{|l|}{ Canada } \\
\hline $\operatorname{VECM}(1,1)$ & -582.04 \\
\hline $\operatorname{VECM}(2,2)$ & -609.15 \\
\hline $\operatorname{MS}(2)-\operatorname{VECM}(1,1)$ & -569.82 \\
\hline $\operatorname{MS}(2)-\operatorname{VECM}(2,2)$ & -591.35 \\
\hline $\operatorname{MS}(3)-\operatorname{VECM}(1,1)$ & -619.57 \\
\hline $\operatorname{MS}(3)-\operatorname{VECM}(2,2)$ & -645.18 \\
\hline \multicolumn{2}{|l|}{ Japan } \\
\hline $\operatorname{VECM}(1,1)$ & -617.82 \\
\hline Model & AIC \\
\hline $\operatorname{VECM}(2,2)$ & -646.34 \\
\hline $\operatorname{MS}(2)-\operatorname{VECM}(1,1)$ & -575.86 \\
\hline $\operatorname{MS}(2)-\operatorname{VECM}(2,2)$ & -599.38 \\
\hline $\operatorname{MS}(3)-\operatorname{VECM}(1,1)$ & -632.54 \\
\hline $\operatorname{MS}(3)-\operatorname{VECM}(2,2)$ & -652.16 \\
\hline \multicolumn{2}{|l|}{ France } \\
\hline $\operatorname{VECM}(1,1)$ & -614.38 \\
\hline $\operatorname{VECM}(2,2)$ & -635.17 \\
\hline $\operatorname{MS}(2)-\operatorname{VECM}(1,1)$ & -583.42 \\
\hline $\operatorname{MS}(2)-\operatorname{VECM}(2,2)$ & -618.16 \\
\hline $\operatorname{MS}(3)-\operatorname{VECM}(1,1)$ & -629.84 \\
\hline $\operatorname{MS}(3)-\operatorname{VECM}(2,2)$ & -640.15 \\
\hline \multicolumn{2}{|l|}{ Italy } \\
\hline $\operatorname{VECM}(1,1)$ & -596.16 \\
\hline $\operatorname{VECM}(2,2)$ & -614.40 \\
\hline $\operatorname{MS}(2)-\operatorname{VECM}(1,1)$ & -578.83 \\
\hline $\operatorname{MS}(2)-\operatorname{VECM}(2,2)$ & -591.39 \\
\hline $\operatorname{MS}(3)-\operatorname{VECM}(1,1)$ & -620.45 \\
\hline $\operatorname{MS}(3)-\operatorname{VECM}(2,2)$ & -646.52 \\
\hline
\end{tabular}

significant relationship between the change in the lagged value of real interest rates and the change in the lagged value of gold prices in both regimes, with the impact being stronger in the recessionary phase. We can thus conclude that gold prices can act as a hedge against real interest rate movements during recessionary times. The results for the remaining six economies remain persistently similar, with the findings matching the turning business cycle points.

Robustness checks are also undertaken including more drivers for gold prices, including consumer prices, real GDP, exchange rates, oil prices, silver prices, copper prices and stock prices. These findings again suggest a positive association between gold prices and real interest rates, with these estimates remaining positive and statistically significant across all G7 countries. The higher effect impact is exhibited once again in the case of the US, suggesting a leading role for the US in the global economic outlook. In terms of the alternative asset investments, the effect of silver and copper prices is negative across all seven economies indicating the competitive portfolio role of those assets against gold prices. As opposed to this, oil prices exert a positive impact on gold prices, illustrating the role of oil for inflationary pressures. Inflation has a positive impact on gold prices, suggesting the higher uncertainty associated with inflation rates, while the effect of income on gold 
Table 9

Multivariate results of the non-linear $\operatorname{MS}(2)-\operatorname{VECM}(1,1)$ model for gold prices and real interest rates.

\begin{tabular}{|c|c|c|c|c|c|}
\hline & & \multicolumn{2}{|l|}{ Regime 1} & \multicolumn{2}{|l|}{ Regime 2} \\
\hline & & $\Delta \mathrm{gp}$ & $\Delta \mathrm{lr}$ & $\Delta \mathrm{gp}$ & $\Delta \mathrm{lr}$ \\
\hline \multicolumn{6}{|l|}{ US } \\
\hline Error correction & & $-0.077[0.01]$ & $-0.086[0.01]$ & $-0.197[0.00]$ & $-0.216[0.00]$ \\
\hline \multicolumn{6}{|l|}{ Transition matrix } \\
\hline & Regime 1 & Regime 2 & Obs. & Ergodic probability & Duration \\
\hline Regime 1 & 0.271 & 0.226 & 120.3 & 0.639 & 116 \\
\hline Regime 2 & 0.184 & 0.598 & 47.1 & 0.361 & 52 \\
\hline \\
\hline Error correction & & $-0.079[0.00]$ & $-0.092[0.00]$ & $-0.158[0.00]$ & $-0.175[0.00]$ \\
\hline \multicolumn{6}{|l|}{ Transition matrix } \\
\hline & Regime 1 & Regime 2 & Obs. & Ergodic probability & Duration \\
\hline Regime 1 & 0.242 & 0.190 & 102.8 & 0.781 & 104 \\
\hline Regime 2 & 0.159 & 0.546 & 64.2 & 0.219 & 64 \\
\hline \multicolumn{6}{|l|}{ Germany } \\
\hline Error correction & & $-0.083[0.00]$ & $-0.102[0.00]$ & $-0.166[0.00]$ & $-0.190[0.00]$ \\
\hline \multicolumn{6}{|l|}{ Transition matrix } \\
\hline & Regime 1 & Regime 2 & Obs. & Ergodic probability & Duration \\
\hline Regime 1 & 0.264 & 0.191 & 78.1 & 0.744 & 104 \\
\hline Regime 2 & 0.162 & 0.557 & 89.3 & 0.256 & 10 \\
\hline \multicolumn{6}{|l|}{ Canada } \\
\hline Error correction & $-0.079[0.00]$ & $-0.095[0.00]$ & $-0.162[0.00]$ & $-0.179[0.00]$ & \\
\hline \multicolumn{6}{|l|}{ Transition matrix } \\
\hline & Regime 1 & Regime 2 & Obs. & Ergodic probability & Duration \\
\hline Regime 1 & 0.251 & 0.188 & 79.3 & 0.713 & 143 \\
\hline Regime 2 & 0.159 & 0.527 & 88.4 & 0.287 & 25 \\
\hline \multicolumn{6}{|l|}{ Japan } \\
\hline \multirow{3}{*}{$\begin{array}{l}\text { Error correction } \\
\text { Transition matrix }\end{array}$} & & $-0.072[0.00]$ & $-0.090[0.00]$ & $-0.177[0.00]$ & $-0.1194[0.00]$ \\
\hline & & & & & \\
\hline & Regime 1 & Regime 2 & Obs. & Ergodic probability & Duration \\
\hline Regime 1 & 0.288 & 0.211 & 60.6 & 0.319 & 67 \\
\hline Regime 2 & 0.169 & 0.597 & 106.2 & 0.681 & 101 \\
\hline \multicolumn{6}{|l|}{ France } \\
\hline Error correction & & $-0.078[0.00]$ & $-0.089[0.00]$ & $-0.152[0.00]$ & $-0.169[0.00]$ \\
\hline \multicolumn{6}{|l|}{ Transition matrix } \\
\hline & Regime 1 & Regime 2 & Obs. & Ergodic probability & Duration \\
\hline Regime 1 & 0.234 & 0.171 & 79.5 & 0.725 & 104 \\
\hline Regime 2 & 0.155 & 0.535 & 87.1 & 0.275 & 10 \\
\hline \multicolumn{6}{|l|}{ Italy } \\
\hline Error correction & & $-0.068[0.01]$ & $-0.082[0.00]$ & $-0.133[0.00]$ & $-0.150[0.00]$ \\
\hline \multicolumn{6}{|l|}{ Transition matrix } \\
\hline & Regime 1 & Regime 2 & Obs. & Ergodic probability & Duration \\
\hline Regime 1 & 0.243 & 0.165 & 78.3 & 0.699 & 104 \\
\hline Regime 2 & 0.141 & 0.504 & 88.7 & 0.301 & 10 \\
\hline
\end{tabular}

Figures in brackets denote p-values.

prices is positive, suggesting a wealth effect for gold prices. Across all seven cases, the ergodic probability and transition matrices recommend the dominant role of the first regime. Once again, both regimes illustrate the presence of a substantial adjustment of gold prices towards long-run equilibrium, which gets stronger in the second regime, suggesting that gold prices adjust faster during recessions. The results therefore indicate that gold prices display a strong hedging behavior for interest rates during recessions. 


\section{References}

Aggarwal, R., Lucey, B.M., O'Connor, F.A., 2014. Rationality in precious metals markets: evidence of behavioural deviations in the gold markets. J. Multinatl. Financ. Manage., 110-130

Aizenman, J., Chinn, M.D., Ito, H., 2016. Monetary policy spillovers and the trilemma in the new normal: periphery country sensitivity to core country conditions. J. Int. Money Finance 68, 298-330.

Ang, A., Bekaert, G., 2002. International asset allocation with regime shifts. Rev. Finan. Stud. 15, 1137-1187.

Amadeo, K., 2017. Gold Prices and the U.S Economy: Secrets of Today’s Gold Prices, The Balance, 7th November, 2017. https://www.thebalance.com/goldprices-and-the-u-s-economy-3305656 (retrieved 11th January 2018).

Apak, S., Akman, V., Çankaya, S., Sönmezer, S., 2012. The case for gold revisited: a safe heaven or a hedge? Emerg. Markets J. 2, 1-8.

Bampinas, G., Panagiotidis, T., 2015. Are gold and silver a hedge against inflation? A two century perspective. Int. Rev. Financ. Anal. 41, 267-276.

Banerjee, A., Marcellino, M., 2006. Are there any reliable leading indicators for US inflation and GDP growth? Int. J. Forecast. 22, 137-151.

Bapna, I., Sood, V., Kumar, N., Harmender, T., Saluja, S., 2012. Dynamics of macroeconomic variables affecting price innovation in gold: a relationship analysis. Pac. Bus. Rev. Int. 5, 1-9.

Barsky, R.B., Summers, L.H., 1988. Gibson's paradox and the gold standard. J. Pol. Econ. 96, 528-550.

Batten, J., Ciner, C., Lucey, B., 2013. On the economic determinants of the gold-inflation relation. Resour. Policy 41, $101-108$.

Baur, D., 2011. Explanatory mining for gold: Contrasting evidence from simple and multiple regressions. Res. Pol. 36, 265-275.

Baur, D.G., Lucey, B.M., 2010. Is gold a hedge or a safe haven? An analysis of stocks, bonds and gold. Financ. Rev. 45, $217-229$.

Baur, D., McDermott, T., 2010. Is gold a safe haven? International evidence. J. Bank. Finance 34, 1886-1898.

Bekiros, S.D., Diks, C.G., 2008. The relationship between crude oil spot and futures prices: cointegration, linear and nonlinear causality. Ener. Econ. 30, 26732685.

Belke, A., 2013. Gold-backed sovereign bonds: an effective alternative to OMTs. In: Maltritz, D., Berlemann, M. (Eds.), Financial Crises, Sovereign Risk and the Role of Institutions. Springer, Heidelberg, pp. 7-24.

Bhar, R., Hammoudeh, S., 2011. Commodities and financial variables: analysing relationships in a changing regime environment. Int. Rev. Econ. Finance 20, 469-484.

Boivin, J., Ng, S., 2006. Are more data always better for factor analysis? J. Econ. 132, 169-194.

Cai, J., Chueng, Y., Wong, M., 2001. What moves the gold market. J. Futures Markets 21, 257-278.

Capie, F., Mills, T.C., Wood, G., 2005. Gold as a hedge against the dollar. J. Int. Financ. Markets Inst. Money 15, $343-352$.

Cecchetti, S.G., Chu, R.S., Steindel, C., 2000. The unreliability of inflation indicators. Curr. Iss. Econ. Finance 6, 1-6.

Ciner, C., 2015. Time variation in systematic risk, returns and trading volume: evidence from precious metals mining stocks. Int. Rev. Financ. Anal. 41, 277283.

Dempster, N., Artigas, J.C., 2009. Gold as a Tactical Inflation Hedge and Long-Term Strategic Asset. World Gold Council, London, UK.

Diba, B., Grossman, H., 1984. Rational bubbles in the price of gold. NBER Working Paper, No. 1300, Cambridge, MA.

Ehrmann, M., Gambacorta, L., Martinez Pagés, J., Sevestre, P., Worms, A., 2003. Financial systems and the role of banks in monetary policy transmission in the Euro area. In: Angeloni, I., Kashyap, A., Mojon, B. (Eds.), Monetary Policy Transmission in the Euro Area. Cambridge University Press, Cambridge.

Elliott, G., Rothenberg, T.J., Stock, J., 1996. Efficient tests for an autoregressive unit root. Econometrica 64, $813-836$.

Erb, C., Harvey, C., 2013. The golden dilemma. NBER Working Paper, No. 18706, Cambridge, MA.

Ewing, B., Malik, F., 2013. Volatility breaks between gold and oil futures under structural breaks. Int. Rev. Econ. Finance $25,113-121$.

Fortune, J.N., 1987. The inflation rate of the price of gold, expected prices and interest rates. J. Macroecon. 9, 71-82.

Garbade, K., Silber, W., 1983. Futures contracts on commodities with multiple varieties. J. Bus., 249-272

Garcia, R., Perron, P., 1996. An analysis of the real interest rate under regime shifts. Rev. Econ. Stat. 78, 111-125.

Gaur, A., Bansal, M., 2010. A comparative study of gold price movements in Indian and global markets. Indian J. Finance 4, $32-37$.

Hamilton, J.D., 1989. A new approach to the economic analysis of nonstationary time series and the business cycle. Econometrica $57,357-384$.

Hamilton, J.D., 1998. The supply and demand for Federal Reserve Deposit. Carnegie-Rochester Conference Series on Public Policy 49 , 1-44.

Hammoudeh, S., Li, H., 2004. Risk-return relationships in oil-sensitive stock markets. Finan. Lett. 2, 10-15.

Johansen, S., 1988. Statistical analysis of cointegration vectors. J. Econ. Dynam. Cont. 12, 231-254.

Kanas, A., Tsiotas, G., 2005. Real interest rates linkages between the USA and the UK in the postwar period. Inter. J. Fin. Econ. 10, $251-262$.

Kim, C.J., Nelson, C., 1998. Business cycle turning points: a new coincident index, and tests of duration dependence based on a dynamic factor model with regime switching. Rev. Econ. Stat. 80, 188-201.

Kiohos, A., Sariannidis, N., 2010. Determinants of the asymmetric gold market. Investment Manage. Financ. Innov. 7, $26-33$.

Krolzig, H.M., 1999. Improving on data mining reconsidered. Econ. J. 2, 202-219.

Lam, S.L., 1990. Economic sanctions and the success of foreign policy goals: A critical evaluation. Japan World Econ. 2, $239-248$.

Lawrence, C., 2003. Why is Gold Different from Other Assets? An Empirical Investigation. World Gold Council, London.

Levin, E., Abhyankar, A., Ghosh, D., 1994. Does the gold market reveal real interest rates? Manchester School 62, 93-103.

Levin, E.J., Montagnoli, A., Wright, R.E., 2006. Short Run and long-run determinants of the price of gold. World Gold Council Research Study, No. 32.

Ma, C., 1985. Spreading between the gold and silver markets. J. Futures Markets 5, 579-594.

Martha, S., Tran, K., 2007. Determinants of the physical demand for gold: evidence from panel data. Working Paper, Department of Economics, American University.

O'Connor, F., Lucey, B., Batten, J., Baur, D., 2015. The financial economics of gold - a survey. Int. Rev. Financ. Anal. 41, $186-205$.

Roache, S.K., Rossi, M., 2009. The effects of economic news on commodity prices: is gold just another commodity? Working Paper, No. 140, International Monetary Fund.

Reboredo, J., 2013. Is gold a hedge or safe haven against oil price movements. Resour. Policy 38, 130-137.

Saikkonen, P., 1992. Estimation and testing of cointegrated systems by an autoregressive approximation. Econ. Theo. 8, 1-27.

Samanta, S.K., Zadeh, A.H., 2012. Co-movements of oil, gold, the US dollar and stock prices. Modern Econ. 3, $111-117$.

Sarno, L., Valenete, G., 2005. Empirical exchange rate models and currency risk: some evidence from density forecasts. J. Int. Mon. Finan. 24, 365-385.

Sjaastad, L., Scacciavillani, F., 1996. The price of gold and exchange rates. J. Int. Money Finance 15, 879-897.

Tulley, E., Lucey, B., 2007. A Power GARCH examination of the gold market. Res. Int. Bus. Finance 21, 316-325.

Wahab, M., Cohn, R., Lashgan, M., 1994. J. Futures Markets 14, 709-756.

Wang, Y.S., Chueh, Y.L., 2013. Dynamic transmission effects between the interest rate, the US dollar, and gold and crude oil prices. Econ. Model. $30,792-798$.

Wang, M., Wang, C., Huang, T., 2010. The relationships between oil prices, gold prices, exchange rates and international stock market prices. Int. Res. J. Finance Econ. 47, 80-89.

Warda, N., Zakaria, M., Nawaz, F.K., 2014. The impact of macroeconomic factors upon gold prices in Pakistan. Pakistan J. Soc. Sci. 34, $383-395$. 